研 究

\title{
能登珪藻土を用いた酸化脱臭触媒の合成
}

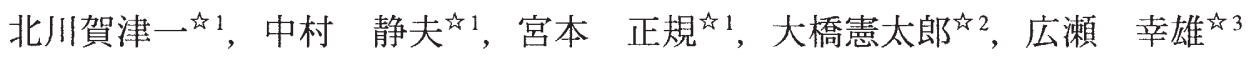 \\ 的1 石川県工業試験場, 广 921-8203 金沢市鞍月 2-1. \\ 42 金沢工業大学，干921-8501 石川県野々市町扇が丘 7-1. \\ 的 3 金沢大学, T920-1164 金沢市角間町。
}

\section{Synthesis of Deodorant Catalyst using Noto-diatomaceous Earth}

 \\ in Industrial Research Institute of Ishikawa, 2-1 Kuratsuki, Kanazawa 920-8203, Japan \\ ${ }^{2}$ Kanazawa Institute of Technology, 7-1 Ohugigaoka Nonoichi-machi, Ishikawa 921-8501, Japan \\ ${ }^{4} 3$ Kanazawa University, Kakuma-machi, Kanazawa 920-1164, Japan
}

Received January 15, 2007

\section{SYNOPSIS}

Noto-diatomaceous earth is porous material that is composed of diatom shell and clay mineral. The pore of diatom shell is macro pore, and the pore of clay mineral is nano meter size pore. Pellet type catalyst carrier was prepared from Noto-diatomaceous earth. Deodorant catalyst was synthesized using this carrier. The catalyst performance was evaluated with fixed-bed continuous-flow reactor using $0.2 \% \mathrm{CO}-2 \% \mathrm{O}_{2}-\mathrm{N}_{2}$ mixed gas. The $\mathrm{CO}$ oxidation was occurred at room temperature by powder type $\mathrm{Pd}$-catalyst. In case of pellet type Pd-catalyst, $\mathrm{CO}$ oxidation occurred at $170^{\circ} \mathrm{C}$.

\section{KEY WORDS}

diatomaceous earth, carrier, deodorant catalyst, palladium

\section{1 緒 言}

石川県能登半島で採掘される能登珪藻土は埋蔵量が27億卜 ンと推定され日本最大である. 能登珪藻土は粘土鉱物を多く 含み成形性に富むので, 輪島塗の下地材, 耐火断熱レンガ, コ ンロ, 土壌改良材に用いられている ${ }^{1}$. 現在は能登地域の振興 として能登珪藻土の新規分野への用途開発が求められている.

日本の高度経済成長時代に発生した公害の問題に対して豊 かさと環境保全の両立を目指して多くの新技術が開発されて きた，脱臭触媒はその技術の一つで，工場からの有害有機物 の除去や，廃棄物処理で発生する悪臭や有害物質を除去する のに用いられている.

この触媒は触媒物質単独で使用されることは少なく, 表面 積を大きくするためや耐熱性を上げるために通常は担体と呼 ばれる多孔質材料表面に触媒微粒子を担持させる ${ }^{2,3)}$. 珪藻殼 粒子は, 電子顕微鏡レベルのマクロ細孔を多数持つ. 他方, 能 登珪藻土に含まれる粘土鉱物はナノメートルサイズの細孔を 形成する、マクロ細孔はガスの拡散に, ナノ細孔は触媒微粒 子の吸着に有効である ${ }^{4.5}$. さらに非晶質シリカから構成され る珪藻殼は化学的に安定である.

本研究では能登珪藻土から担体を試作し, 触媒微粒子を担
持した酸化脱臭触媒を合成し, 一酸化炭素をモデルガスに用 いて酸化反応を評価解析した.

\section{2 試料及び実験方法}

2.1 触媒の合成

能登珪藻土は耐火断熱レンガやコンロ(七輪)に活用されて いる七尾地区和倉珪藻泥岩を使用した. 粉末担体は能登珪藻 土の乾燥粉末を使用した。ペレット形状の担体は真空土練機 (三庄インダストリ一製: V-15 UNI-X) で試作した. 能登珪藻 土に所定量の水を加えた練土を真空土練機でシリンダ形状に 押出成形した. 成形体はカッターで $5 \mathrm{~mm}$ 角に切断し電気炉 にて $700^{\circ} \mathrm{C}$ で焼成した.

脱臭触媒は以下の方法で合成した. $\mathrm{PdCl}_{2}$ と 2 倍モル量の $\mathrm{NaCl}$ を秤量し, 吸水量に相当する $1: 1 \mathrm{HCl}$ を加え加温溶解し た ${ }^{6)}$. 珪藻土担体に上記 $\mathrm{NaPdCl}_{4}$ 水溶液を含浸法で吸着し 100 ${ }^{\circ} \mathrm{C}$ で乾燥し固定化した後に電気炉で坩堝に炭を充填した還元 雾囲気で $500^{\circ} \mathrm{C}$ に焼成し 3 重量\%Pd- 珪藻土等の触媒を合 成した。

\section{2 物性測定}

室素ガス細孔分布測定は(日本ベル製: BELSORP28-SA)で, 
水銀圧入法による細孔分布测定は (ユアサアイオニクス製： POWERSTER60)で行った。 鉱物の同定は, X線回折装置(マッ クサイエンス製: MXP-18A)で行った. 電子顕微鏡写真は, 走 査型及び透過型電子顕微鏡 (日立製作所製：H800) で測定し た. 触媒性能評価解析は固定床流通反応装置で, 標準ガス $\left(0.2 \% \mathrm{CO}-2 \% \mathrm{O}_{2}-\mathrm{N}_{2}\right.$ バランス) を触媒体積 $3 \mathrm{ml}$ にガス空間速度 $\left(\mathrm{SV}=\mathrm{F} / \mathrm{V}=1000 \mathrm{hr}^{-1}, \mathrm{~F}\right.$ は反応ガスの体積供給速度 $(\mathrm{ml} / \mathrm{s}), \mathrm{V}$ は触媒体積 $(\mathrm{ml}))$ で室温から $300^{\circ} \mathrm{C}$ までの温度範囲で流し, 触 媒層を通過した反応ガスをマイクロシリンジで採取してガス クロマトグラフ測定装置(島津製作所製: GC8A)で分析した. 検出器は熱伝導度型検出器 (TCD) を用いた. カラム充填剤に は合成ゼオライトのモレキュラシーブ $5 \mathrm{~A}\left(\mathrm{Na}^{+}\right.$イオンの $1 / 3$ ま たはそれ以上を $\mathrm{Ca}^{2+}$ イオンで置換して得られる細孔の有効直 径 5 Åのもの) )使用した。

\section{3 実験結果および考察}

\section{1 ガスクロマトグラフ分析}

標準ガスのガスクロマトグラムを Fig.1に示す. 第1番目に 酸素ガスのピークが，2 番目に窒素ガスのピークが，最後に は一酸化炭素ガスのピークがあらわれる.この保持時間の違 いはモレキュラシーブ $5 \mathrm{~A}$ に対する 3 種類のガス $\left(\mathrm{CO}, \mathrm{O}_{2}, \mathrm{~N}_{2}\right)$ の分子の大きさと吸着作用の違いによる. 反応では $\mathrm{CO}$ の $\mathrm{CO}_{2}$ への転化率 (Conversion) はCO ガスクロマトグラム面積が反 応後にどの程度減少するかで算出した.

Fig.2は力ラム温度と保持時間を調べた結果である. 酸素ガ ス窒素ガスいずれもカラム温度が高くなると保持時間が短く なった。一般に式(1)が成立する7).

$$
\operatorname{In} V_{R S}=-\frac{\Delta H_{S}}{R T}
$$

$\mathrm{V}_{\mathrm{SR}}$ は比保持容量, $\Delta \mathrm{H}_{S}$ は1 モルあたりの溶解熱, $\mathrm{R}$ は気体定 数，Tは絶対温度である.よってカラム温度が上がれば保持 時間は短くFig. 2 と対応がつく. 一般的にはカラム温度が低い ほどピークの分離が良くなる. 標準ガスの分離性から Fig.1に

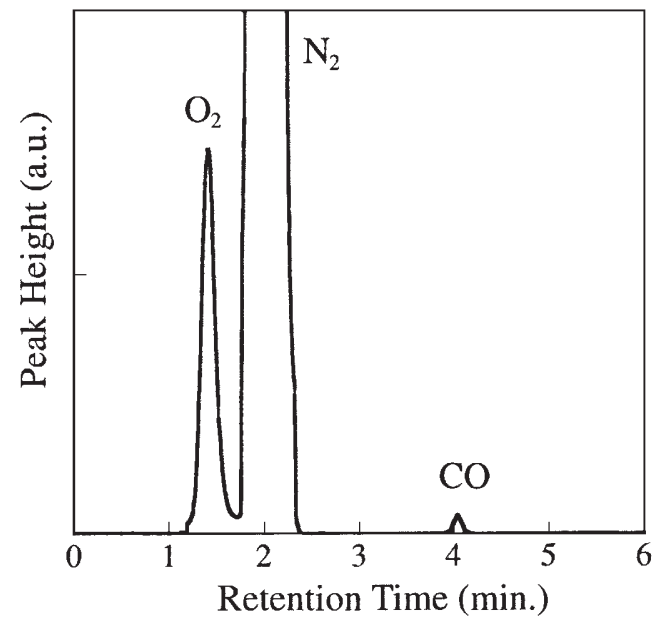

Fig.1 Gas chromatogram pattern of $0.2 \% \mathrm{CO}-2 \% \mathrm{O}_{2}-97.8 \% \mathrm{~N}_{2}$ mixed standard gas.
示すようにカラム温度は $150^{\circ} \mathrm{C}$ とした。

\section{2 能登珪藻土と脱臭触媒の物性}

Fig.3 (a) に示すように能登珠藻土は主に珠藻殻から構成さ れる. 珪藻殼は様々な形態をとる. 能登珠藻土は珪藻殻のほ かには粘土鉱物，石英，長石，有機物，硫黄化合物など様々

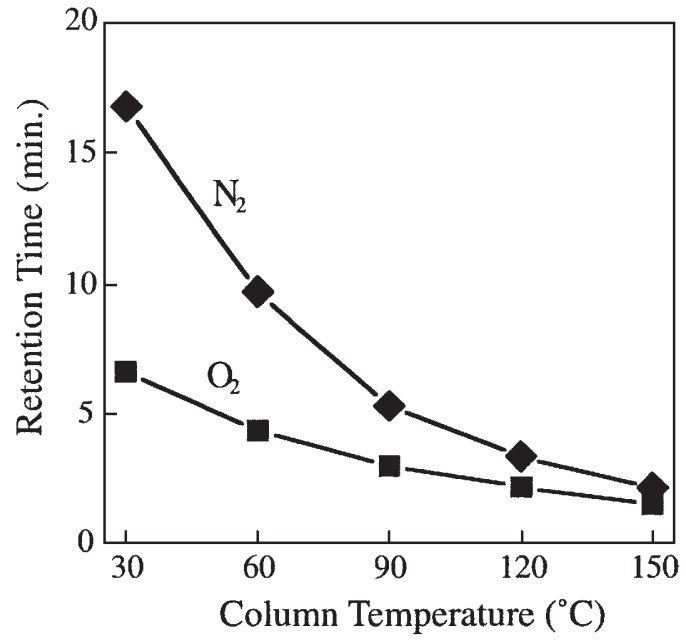

Fig.2 Column temperature of gas chromatograph and retention time of $\mathrm{O}_{2}$ and $\mathrm{N}_{2}$ peak.

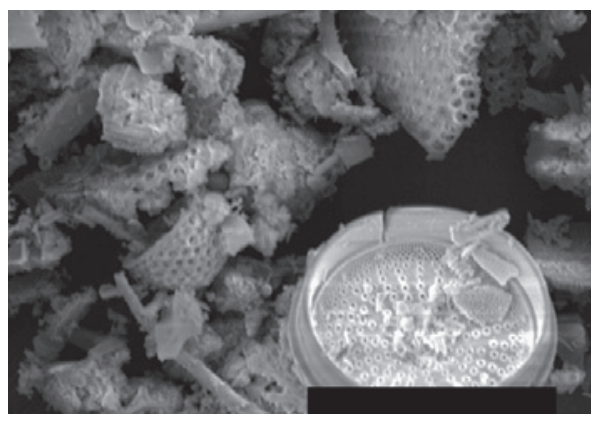

$50 \mu \mathrm{m}$

(a)Noto-diatomaceous earth



(b)diatom shell

Fig.3 Microstructures of Noto-diatomaceous shell and clay by SEM. 
な物質から構成される ${ }^{1)}$. 珪藻殼自体は非晶質シリカから出 来ていてFig.3(b)のように $2 \mu \mathrm{m}$ 程度の大きなマクロ細孔を多 数形成する多孔質材料である. 能登珪藻土を水箕分級し粘士 鉱物が濃縮した部分を電子顕微鏡観察したものが Fig.4であ る. 通常の電子顕微鏡写真では粘土鉱物を識別することは難 しい. Fig.4 (a) の左上から右下にかけて薄く写っているのが 珪藻殼である，黒く濃く写っているのが粘土鉱物である. 粘 土鉱物は凝集して $1 \mu \mathrm{m}$ 以上の大きな二次粒子となっているも のもある. Fig.4 (b) は拡大写真である.これより主にモンモ リロナイトと考えられる粘土鉱物は 20〜 $50 \mathrm{~nm}$ の等粒子状粒 子が凝集して形成される.

Fig.5 と Fig.6 に水銀圧入法による細孔分布測定と窒素ガス 細孔分布測定結果を示す. IUPAC ${ }^{8)}$ の分類では細孔径 $w$ は $w<$ $2 \mathrm{~nm}$ の細孔がミクロ細孔， $2 \mathrm{~nm}<w<50 \mathrm{~nm}$ の細孔をメソ細 孔， $w>50 \mathrm{~nm}$ をマクロ細孔と呼ぶ. Fig.5 の水銀圧入法によ る細孔分布測定から能登珪藻土の平均細孔径は約 $3 \mu \mathrm{m}(3,000$ nm) でマクロ細孔が中心である. Fig.6の窒素ガス細孔分布測 定結果から, 量的に少ない約 $2 \mathrm{~nm}$ の細孔が能登珪藻土に存在 することが推察される.



$1 \mu \mathrm{m}$

(a)

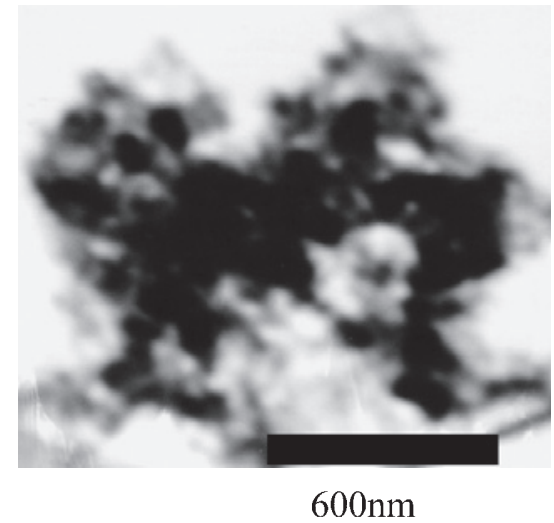

(b)

Fig.4 Microstructures of Noto-diatomaceous shell and clay by TEM.

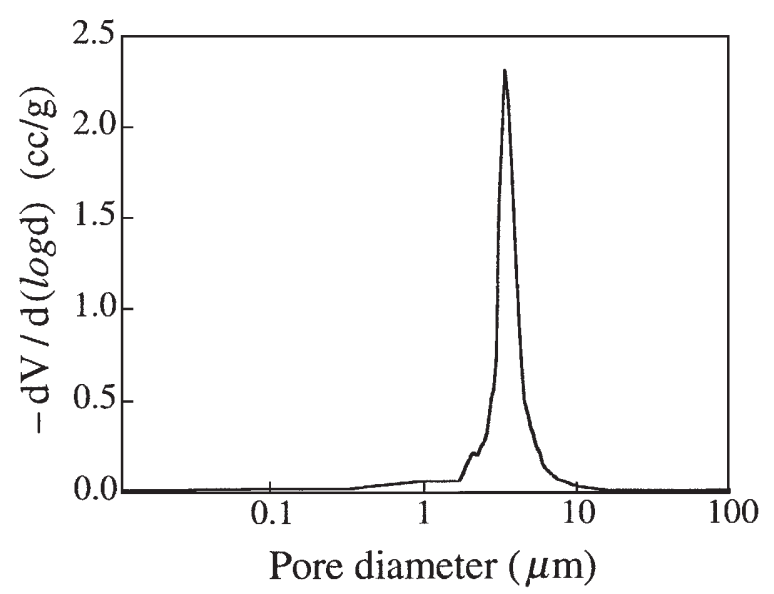

Fig.5 Macro pore size distribution of Noto-diatomaceous earth by mercury porosimetry.

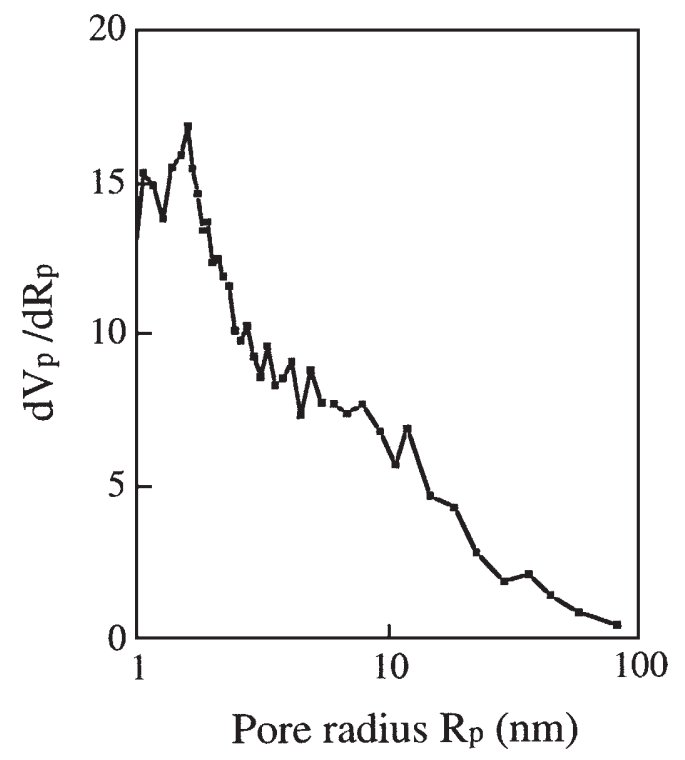

Fig.6 Nitrogen adsorption and desorption data obtained from Noto-diatomaceous earth.

\section{3 脱臭触媒の触媒性能評価}

一酸化炭素の触媒反応メカニズムは以下のように考えられ る9). 一酸化炭素のlinear型の吸着では, 一酸化炭素の非結合 性 $5 \sigma$ 軌道 (孤立電子対) の電子が, 表面金属原子の空軌道に 供与され $\mathrm{M} \leftarrow \mathrm{C}$ の $\sigma$ 結合を形成. つづいて金属の $\mathrm{d}$ 軌道から 一酸化炭素の $2 \pi$ 反結合性空軌道に電子が逆供与 (backdonation) され M-C $\pi$ 結合を形成する.この反結合性軌道への 電子流入によって C-O結合が弱まる. M-CO結合が強まると 逆供与が良く起こるため, 結果 M-CO結合が強まり一酸化炭 素の結合が不安定化して酸素と反応する. 本反応ではニッケ ル, 鉄, モリブデン, マンガンでは反応が進まなかった.ニッ ケル, 鉄, モリブデン, マンガン等の遷移金属元素は CO の 吸着力が強いのでその後の酸化反応が有効に進行しないと解 
釈される.パラジウム $(\mathrm{Pd})$ は室温付近で酸化反応が進行し た. $\mathrm{Pd}$ と $\mathrm{Rh}$ の貴金属元素は $\mathrm{CO}$ の触媒表面への吸着，電子 供与, 電子逆供与, $\mathrm{CO}$ 結合の不安定化そして酸化反応の進行 という一連の反応メカニズムがスムーズに進行するために触 媒として有効に作用したと考えられる。

次に $3 \%$ のパラジウム $(\mathrm{Pd})$ を担持した触媒の形状を粉末と ペレットで変えた場合の触媒のCO酸化反応結果をFig.7に示 す．粉末触媒は室温付近で反応が進行するのに対して，ペ レット形状触媒は $170^{\circ} \mathrm{C}$ 付近で反応が進行した. Fig.8は通常 の酸化焼成と炭(カーボン)による還元雾囲気焼成でペレット 形状の CO 酸化反応の性能を調べた結果である．還元雾囲気 焼成は $170^{\circ} \mathrm{C}$ 反応が進行するのに対して, 酸化雾囲気焼成 では $250^{\circ} \mathrm{C}$ 以上でないと反応が進行しない. パラジウム元素 は還元雾囲気で触媒性能が高く, 触媒表面の酸化還元状態が

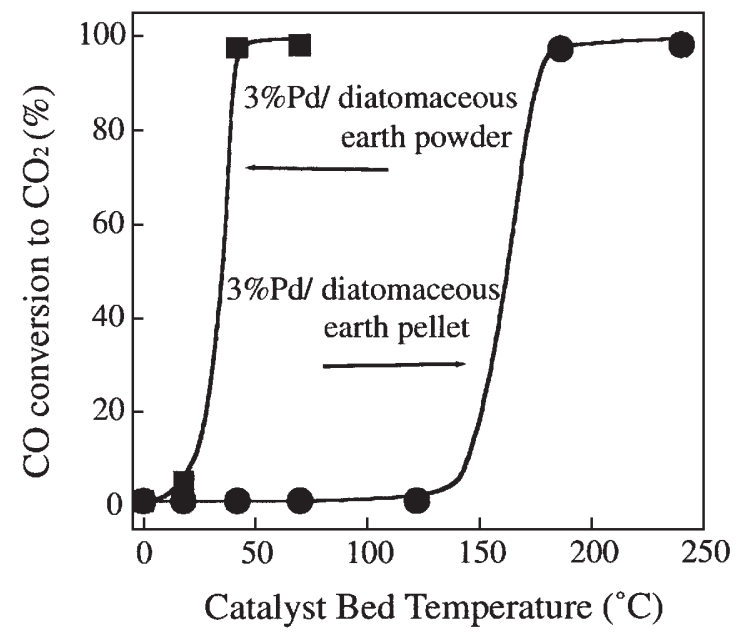

Fig.7 Reaction conversion $v s$. catalyst bed temperature of $3 \% \mathrm{Pd} /$ Noto-diatomaceous earth powder and $3 \% \mathrm{Pd} /$ Notodiatomaceous earth pellet catalyst.

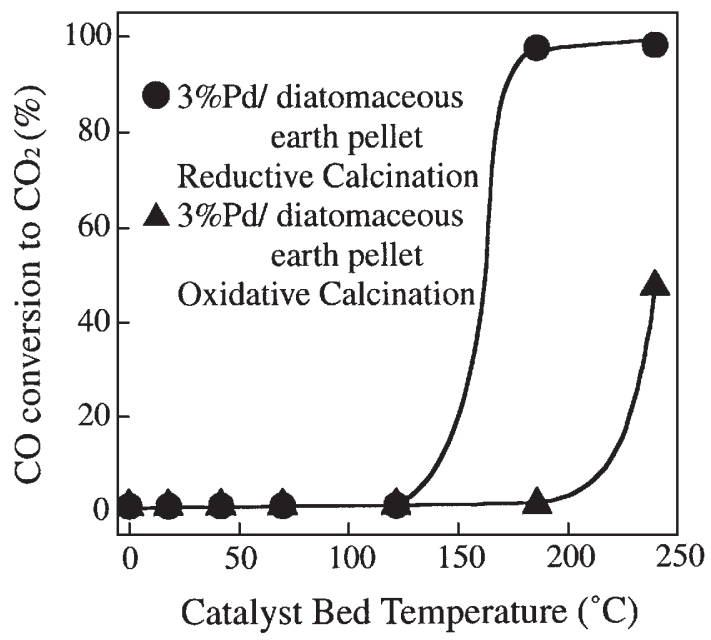

Fig. 8 Reaction conversion $v s$. catalyst bed temperature of $3 \% \mathrm{Pd} /$ Noto-diatomaceous earth pellet catalyst with different calcination conditions.
重要である. ガス空間速度(SV)を $1000 \mathrm{hr}^{-1}$ から $8000 \mathrm{hr}^{-1}$ まで 変化させた場合の $200^{\circ} \mathrm{C}$ におけるCO酸化反応結果を Fig. 9 に 示す. $\mathrm{SV}=1000 \mathrm{hr}^{-1} \sim 4000 \mathrm{hr}^{-1}$ までは $100 \%$ 反応が進行する が, SV $=8000 \mathrm{hr}^{-1}$ では反应率は $20 \%$ に低下した. ガス空間速 度が上がることで触媒層でのガス接触時間が反比例的に減少 してガス吹き抜けが発生している.

Fig. 10 は $0.5 \% \mathrm{Pd}-5 \% \mathrm{~W} /$ 能登珪藻土ペレットの X 線回折パ ターンである. 還元雾囲気焼成をした試料である.パラジウ ム酸化物とタングステン酸化物のピークが観測された。 $0.5 \% \mathrm{Pd}-5 \% \mathrm{~W} /$ 能登珪藻土ペレットと $3 \% \mathrm{Pd} /$ 能登珪藻土ペレッ トの CO 酸化反応結果を Fig. 11 に示す. パラジウムの担持量 を減らすとCO酸化反応はほとんど進行しなくなる. $0.5 \%$ の パラジウムに鉄, ニッケル, マンガンなど他の元素を添加し た場合も同様である.しかし，5\%のタングステンを添加した 場合は若干 CO 酸化反応の立ち上がり温度が高温側に移動す るが, $3 \% \mathrm{Pd} /$ 能登珪藻土ペレットと比較して同等の触媒性能



Fig.9 Reaction conversion $v$ s. catalyst bed temperature of $3 \% \mathrm{Pd} /$ Noto-diatomaceous earth pellet catalyst with different space velocity.

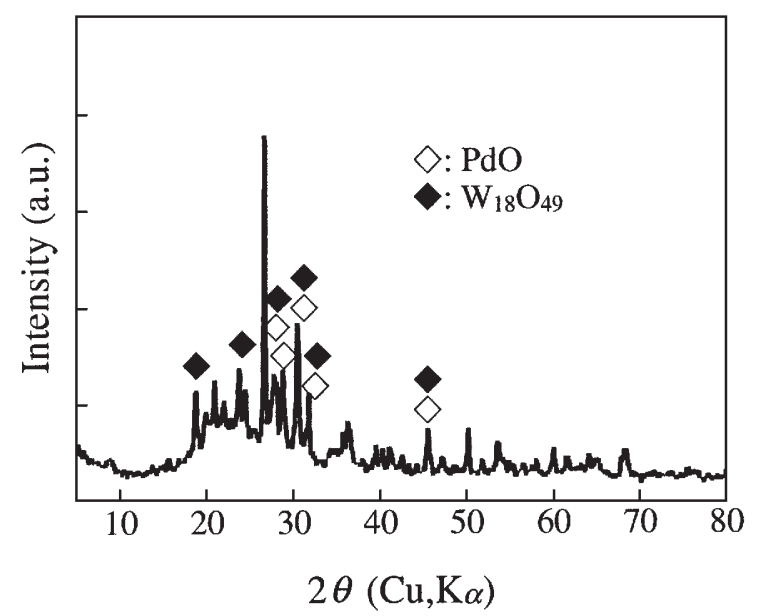

Fig.10 XRD pattern of $0.5 \% \mathrm{Pd}-5 \% \mathrm{~W} /$ Noto-diatomaceous earth pellet. 


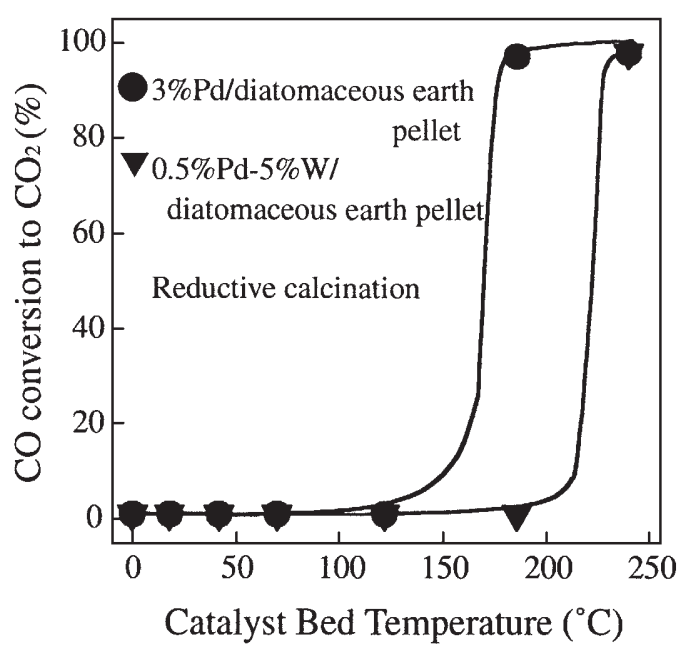

Fig.11 Reaction conversion $v s$. catalyst bed temperature of $3 \% \mathrm{Pd} /$ Noto-diatomaceous earth pellet catalyst and $0.5 \% \mathrm{Pd}-5 \% \mathrm{~W} /$ Noto-diatomaceous earth pellet catalyst.

が得られた. 以上より少量のタングステンを添加すると高価 なパラジウムの使用量を抑えながら触媒性能を発揮すること ができることがわかった.

能登珪藻土はマクロ細孔が多くその他メり細孔, ミクロ細 孔も配置されている. 能登珪藻土のメソ細孔及びミクロ細孔 に毛細管凝縮作用で $\mathrm{NaPdCl}_{4}$ 水溶液が吸水される. その後吸 着, 固定, 還元焼成で Pd微粒子が能登珪藻土の表面に分散固 定化される.この脱臭触媒に悪臭成分ガスを流すと, マクロ 細孔はガス拡散の流路を提供する ${ }^{4,5)}$. そしてメソ細孔ないし ミクロ細孔に分散されたPd微粒子表面に吸着して空気中の酸 素と反応する

\section{4 ま と め}

能登珪藻土を用いて押出成形法で担体を試作した。この担 体に触媒成分を担持して触媒を合成し, 固定床流通反応装置 で一酸化炭素の酸化反応を行い, 触媒性能を評価解析した.

(1) 能登珪藻土は約 $3 \mu \mathrm{m}$ のマクロ細孔が多い. その他約 $2 \mathrm{~nm}$
のナノ細孔及びメソ細孔が分布する.

(2) 能登珪藻土の主な粘土鉱物はモンモリロナイトである. モンモリロナイトは20〜 $50 \mathrm{~nm}$ の等粒子状に存在する. モ ンモリロナイトの可塑性により真空土練機を用いた押出 成形が可能になる.

(3) 3\%のパラジウム $(\mathrm{Pd})$ を珪藻土に担持した粉末触媒は室温 付近で反店が進行し, ペレット形状触媒は $170^{\circ} \mathrm{C}$ 付近で 反応が進行する.


化雾囲気焼成では $250^{\circ} \mathrm{C}$ 以上でないと反応が進行しない。

(5) $\mathrm{SV}=1000 \mathrm{hr}^{-1} \sim 4000 \mathrm{hr}^{-1}$ までは $100 \%$ 反応が進行するが, $\mathrm{SV}=8000 \mathrm{hr}^{-1}$ では反応率は $20 \%$ に低下する。

(6) $5 \%$ のングステンを添加すると高価なパラジウムの使用 量を抑えながら触媒性能を発揮することができる.

\section{謝辞}

本研究を遂行するに当たり, 貴重なご支援とご助言を頂い たイソライト工業(侏)，丸越工業(侏に謝意を表します.

\section{文献}

1) Ishikawaken Keisodo Riyo Kenkyukai Kisobukai: "Notosan Keisodo no Kisokenkyu", (1966).

2) "Shokubai Sekkei", Catalysis Society of Japan, 5(1985)40-42.

3) K.Onuma: Preparation of Catalysts IV, Elsevier Science Publishers, (1987)543-555.

4) T.Inui and M.Funabiki: Chem. Lett., (1978)251-252.

5) T.Inui, M.Funabiki, M.Suehiro and T.Sezume: JCS, 75(1979) 787-802.

6) Brauer: Prep. Inorg. Chem., 1584.

7) "Gas Chromatography", Hirokawa Publishing Co., (1968)5057.

8) J.Rouquerol, D.Avnir, C.W.Fairbridge, D.H.Everett, J.H.Haynes, N.Pernicone, J.D.F.Ramsay, K.S.W.Sing and K.K.Unger: Pure Appl. Chem., 66(1994)1739-1758.

9) P.M.Williams and P.Butcher, J. Wood: Phys. Rev., B14(1976) 3215-3226. 